\title{
A history of invasion: COI phylogeny of Manila clam Ruditapes philippinarum in Europe
}

Stefania Chiesa $^{\mathrm{a}^{*}, \text { Livia Lucentini }^{\mathrm{b}} \text {, Rosa Freitas }}{ }^{\mathrm{a}}$, Francesco Nonnis Marzano $^{\mathrm{c}}$, Silvia Breda $^{\mathrm{d}}$, Etelvina Figueira $^{\mathrm{a}}$, Nathalie Caill-Milly ${ }^{\mathrm{e}}$, Roger J.H. Herbert ${ }^{\mathrm{f}}$, Amadeu M.V.M. Soares ${ }^{\mathrm{a}}$ and Emanuele Argese $^{\mathrm{d}}$

${ }^{\mathrm{a}}$ Department of Biology \& CESAM, University of Aveiro, Campus de Santiago, 3810-193, Aveiro, Portugal

${ }^{\mathrm{b}}$ Department of Chemistry, Biology and Biotechnologies, University of Perugia, Via Elce di Sotto, 06123, Perugia, Italy.

${ }^{c}$ Department of Life Sciences, University of Parma, Viale delle Scienze 11/a, 43124, Parma, Italy ${ }^{\mathrm{d}}$ Department of Molecular Sciences and Nanosystems, Ca' Foscari University of Venice, Via Torino 155, 30172 Venezia Mestre, Italy.

${ }^{\mathrm{e}}$ Ifremer, Laboratory Halieutic Resources from Aquitaine, UFR Sciences and Technics, 1 allée du Parc Montaury, F-64600, Anglet, France.

${ }^{\mathrm{f}}$ Centre for Conservation Ecology and Environmental Sciences, Faculty of Science and Technology, Bournemouth University, Christchurch House, Fern Barrow, Poole, BH12 5BB, Dorset, United Kingdom.

*Corresponding author. Dr. Stefania Chiesa, Department of Biology \& CESAM, University of Aveiro, 3810-193 Aveiro (Portugal). Phone +351 234370782 fax +351 234 372587. E-mail: stefania.chiesa@ua.pt 
2 The Manila clam Ruditapes philippinarum - synonym Venerupis philippinarum (Adams and Reeve,

3 1850) is now one of the top 5 most commercially valuable bivalve species worldwide. Originally

4 from the Indo-Pacific region, it has been introduced in many countries for fisheries and aquaculture,

5 including estuarine environments along Atlantic and Mediterranean European coasts. Yet despite its

6 commercial value and widespread distribution, the precise origins of stocks remain speculative and

7 the genetic diversity of introduced populations is poorly known. Thus, the aim of this work was to

8 collect mtDNA COI (Cytochrome oxidase I) gene sequences from 5 European countries with

9 Manila clam stocks and compare them with native Asian populations to evaluate their genetic diversity and identify possible routes of invasion. The COI gene sequencing supported a strong founder effect in the European populations with 3 main haplotypes occurring at high frequencies, derived from Japan. However, high haplotype diversity was also observed due to the occurrence of 10 rare haplotypes. This supports hypotheses (i) there have been additional, previous unrecorded, introductions as previously hypothesized by analysis of $16 \mathrm{~S}$ rDNA, and (ii) there has been a limited loss of genetic diversity in introduced populations, as previously suggested by microsatellite data. This is the first genetic comparison of Manila clam populations introduced in to Europe with native clams. Genetic data herein presented are fundamentally important for the traceability of clam products and stock management programmes and will also inform discussion on the potential resilience of exploited Manila clam populations.

Key words Manila clam, COI, genetic diversity, Europe, Non-indigenous species

\section{Introduction}


Among commercially exploited bivalves, the Manila clam Ruditapes philippinarum - synonym Venerupis philippinarum (Adams and Reeve, 1850) is of considerable international importance and considered among the top 5 most commercially valuable bivalve species worldwide (over 250,000 tons for year) (Astorga, 2014). Originally distributed in the Indo-Pacific region it has been introduced in many countries for fisheries and aquaculture (Gosling, 2003), including European Atlantic and Mediterranean coastal waters (Gosling, 2003). As reported by Flassch and Laborgne (1992), until the 1990s the main European stocks originated from a small pool of organisms introduced from North America (see Table 1 for a summary of initial introductions in Europe). Following the available data on licensed introductions, the first introductions in Europe dates back to 1972-1974 in Arcachon Bay, France by IFREMER (Institut Français de Recherche pour l'Exploitation de la Mer). Flassch and Leborgne (1992) reported that a total of 500,000 spat, and 1,000 adults from Puget Sound (South Western Canada, Pacific coast) were introduced into the Arcachon Bay, roughly representing a total biomass of $70 \mathrm{~kg}$. The same population from Puget Sound was used for the first introduction of Manila clam in the UK in 1980, at the MAFF (Ministry of Agriculture, Fisheries and Food) Fisheries Laboratory, Conwy-North Wales (Humphreys et al., 2015). The near-by Menai Strait was identified as the location of the first introduction into UK coastal waters in 1983 (Humphreys et al., 2015). In the same year, the first introduction in the Northern Adriatic Sea also occurred, conducted by the Co.S.PA.V (Consorzio per lo Sviluppo della Pesca e dell'Acquacoltura del Veneto) in the Venice lagoon using seed from Great Britain (Breber, 1985). In a short period of time Manila clam was introduced in other Adriatic coastal lagoons, namely Marano, Caleri, Scardovari, Goro (Pellizzato, 1990). All these first introductions were conducted with clams coming from SeaSalter Shellfish Company (M. Pellizzato, pers. Comm.) which operated from hatcheries in south-east and north-west England, and the company was established with clams from Conwy (Humphreys et al., 2015). In Spain, Manila clam was already occurring in the mid '80s (Perez-Camacho and Cuna, 1985) in many different coastal 
areas (Galicia, Cantabria, Andalusia, and Cataluña). The first report of Manila clam in Portugal dates back to 1984 in Ria Formosa (Algarve) probably originated from Spain (Ruano and Sobral, 2000), even if no information about the status of the Spanish "source" population (hatchery or naturalised) is available. The species is not yet licensed in Portugal (Chainho et al., 2015) even if aquaculture was the most likely vector of introduction (Chainho et al., 2015). However, since the '80s, naturalised Manila clam populations have been reported in many estuarine systems all over the country (Gaspar, 2010; Chainho, 2014; Chainho et al., 2015; Velez et al., 2015a; b). Today Manila clam is considered the dominant bivalve species in the Tagus estuary and is one of the most abundant clams in the Ria de Aveiro and Sado estuary (Chainho, 2014; Velez et al., 2015a). Nowadays, the production of Manila clam in Europe derives mainly from fisheries of naturalised populations, established after human-mediated introductions. This is the case in France, specifically Arcachon Bay, where the whole production derives from the original introduced and naturalised population (Bald et al., 2009; Sanchez et al., 2014), and also England (Humphreys et al., 2015), Spain (e.g. the Bay of Santander- Bidegain and Juanes, 2013) and Portugal (Chainho et al., 2015). Detailed literature data are available for UK, where the first reported naturalized Manila clam population was observed in Poole Harbour (Jensen et al., 2004), where the first licensed introduction dates back to 1988 from seeds originated from Conwy hatchery, and wild clams appeared about two years latter (Humphreys et al., 2015). Between 1980 and 2010 the Manila clam has become naturalized in 11 British estuaries. The most extensive newly established wild populations is in Southampton Water, which lies about $48 \mathrm{~km}$ east of Poole Harbour, and where Manila clam likely arrived in 2002 (Humphreys et al., 2015). It is possible that this has originated via natural larval dispersal from Poole Harbour (Herbert et al., 2012) or anthropogenic means (Humphreys et al., 2015).

Aquaculture facilities have been also successfully established for Manila clam in UK, Italy (Northern Adriatic Sea) and in Spain, especially in Galicia (Robert et al., 2013). In Spain, hatcheries 
mainly provide seeds for local associations of producers. Most of the production takes place in private parks (concessions for a period of years) and on beaches that are managed by local associations (Robert et al., 2013). In Italy, Manila clam spread occurred rapidly, and quickly populations became naturalised (Pellizzato, 1990) thus its exploitation became the most economically important fishing activity, especially in the Venice Lagoon (see Boscolo Brusà et al., 2013 for a complete list of references). However, due to the initial lack of reliable regulation and unsustainable exploitation of fisheries resources, there has been a constant decrease in clam production (Boscolo Brusà et al., 2013), which determinated a recent transition from clam fishing to clam farming activities, and to the rational management of natural spat (Boscolo Brusà et al., 2013). Currently, in the Venice lagoon most clam harvesting is carried out in licensed areas directly managed by farmers (Boscolo Brusà et al., 2013), using seeds derived from natural spat. This system has been already established in other Northern Adriatic Sea lagoons, like Goro lagoon, where the production remained stable for almost 3 decades (Bartoli et al., in press). In general, the problem for Manila clam cultivation in Europe is the same as global shellfish aquaculture: high quality seed availability (Robert et al., 2013). Although efforts have been made to improve the hatchery production, clam farming of Manila clam still depends on natural seeds (Robert et al., 2013).

As underlined in previous paragraphs, Manila clam is a valuable economic resource for some European countries. However, as pointed out by Astorga (2014), although aspects of the species biology have been studied genetic resources are still largely unknown. For several fisheries and aquaculture commercial species, especially fish, biotechnology and genetic research have developed significantly in the last decade (Astorga, 2014); however similar applications for valuable molluscs have been minimal (Astorga, 2008; 2014) and for Manila clam in particular. In fact, whole genome reference sequences, high-density SNP genotyping arrays or genotyping-by-sequencing have been developed especially for fish (Yáñez et al., 2015). As for Manila clam, few studies have been 
devoted to the genetic diversity and structure of populations in its native range (see as examples Sekine et al., 2006; Vargas et al., 2008; Liu et al., 2007; Mao et al., 2011; An et al., 2012; Kitada et al., 2013, Nie et al., 2015) and in introduced ecosystems (Chiesa et al., 2011; 2014; 2016; Mura et al., 2012; Hurtado et al., 2012). Yet a comparative study of native and introduced populations has not previously been undertaken and no genetic information is available concerning the differences occurring among productive stocks worldwide, or potential invasion pathways that might compromise the ability to perform predictions of genetic diversity and population structure of nonindigenous taxa (Holland, 2000).

The genetic structure of an invasive population depends on several factors, including the effective population size at the time of introduction and the genetic diversity of the source population (Holland, 2000). If an introduction occurs as a single event, starting from a limited number of founders, population genetic theory predicts that alleles will be fixed and lost at an accelerated rate relative to the source population (Mayr, 1963; Hartl and Clark, 1997; Holland, 2000). The gene pool of the introduced population is expected to be limited, as a result of the stochastic process of the introduction mechanism (Holland, 2000). However, if the introduction involves a large genetically diverse assortment of individuals, it is expected to have little or no reduction in heterozygosity and allelic diversity relative to the gene pool of the source population (Holland, 2000). In fact, a founding population which derives from numerous previously isolated populations has the potential to produce a genetically highly diverse assortment of offspring. It has been already proposed by Roman and Darling (2007) that invasions from multiple discrete source populations, or admixture, may be the standard rather than the exception in invasion biology and that the cooccurrence of mitochondrial lineages, geographically separated in the native range, could be considered an evidence of multiple introductions events (Taylor \& Keller, 2007). Furthermore, genetic data on Manila clams is fundamental for studies associated with clam traceability and safety, preventing fraud and supporting management programmes of exploited 
populations. This is particularly important for a highly exploited resource like Manila clam, both for fisheries and aquaculture. In fact, the erosion of the genetic diversity determinates a high risk of introgression and a reduction of fitness of the exploited populations, and also their resilience capability as relict populations (Frankham et al., 2010). In the Venice lagoon, an overexploitation of Manila clam that has occurred in the last decades has resulted in a huge reduction of the naturalised population (Boscolo Papo et al., 2013) with possible consequences for genetic diversity and demographic structure.

Previously, studies conducted on Manila clam populations from the Northern Adriatic Sea, Portugal (Ria de Aveiro) and Spain (Galician coast) demonstrated a strong founder effect by 16SrDNA gene sequencing, but also enhanced haplotype diversity occurring in introduced populations (Chiesa et al., 2011, 2014). Moreover, microsatellite genotyping in the same populations showed a limited loss of genetic diversity, and even though several loci were affected by null alleles, globally the number of alleles was comparable to those observed in native Asian populations (Chiesa et al., 2011, 2016; Chiesa et al., in press).

Considering that previous studies on Asian populations were also conducted with COI gene fragment sequencing (Sekine et al., 2006; Mao et al., 2011; Kitada et al., 2013), the present work aimed to collect mtDNA COI gene sequences also from 5 European countries hosting Manila clam aquaculture and fishing activities, and for the first time to compare genetic diversity between these introduced stocks and native Asian populations. This is the first genetic study to investigate invasion routes of Manila clams in Europe and the genetic diversity of commercial stocks, which will contribute to the basic knowledge in the field of invasion biology, and support management programmes of this valuable economic resource in European countries.

\section{Methods}

\subsection{Sampling procedures}


Manila clam was collected from introduced naturalised populations in the Northern Adriatic Sea $(\mathrm{N}=111)$, and along the Atlantic coast in Portugal (Ria de Aveiro lagoon, Óbidos lagoon and Ria Formosa, Tagus and Sado estuaries, $N=71$ ), North Western Spain (Galicia, N = 10), South Western France (Arcachon, N = 15) and Southern UK (Poole Harbour and Southampton, N =16). A total of 223 samples were analyzed. Details on sampling locations are provided in Fig.1 and Table 2. Haplotypes previously identified by $16 S$ rDNA (Chiesa et al., 2014) were resubmitted for COI genotyping.

\subsection{DNA extraction and purification}

High molecular weight genomic DNAs were extracted and purified from ethanol-fixed mantle and foot tissue stored at $-20{ }^{\circ} \mathrm{C}$ using the Wizard genomic DNA Purification kit (Promega) following a standardized protocol (Chiesa et al., 2011; 2014). Ethanol-fixed mantle and foot tissue stored at -20 ${ }^{\circ} \mathrm{C}$ were selected for the extraction to avoid the interferences of the DUI - the Doubly Uniparental Inheritance (Plazzi and Passamonti, 2010). This phenomena was already described in bivalves like Manila clam (Passamonti and Scali, 2001) and blue mussel (Zouros et al., 1994), implying the existence of two mtDNAs in adult males, the so called " $\mathrm{F}$ - type" mitochondrial genome which prevails in somatic tissues, while the so called "M-type" mitochondrial genome is strongly predominant in gonads (Cao et al., 2004). Sperm carry only M-type mtDNAs, which nucleotide sequence can diverge from the F-type mtDNA up to the $30 \%$. For this reason, for phylogenetics and biogeographic analyses the F-type DNA should be selected, due to its maternal inheritance. To avoid the co-extraction and amplification of M-type mtDNA, specific tissues should be selected for DNA extraction, as they carry a very little quantity of M-type mtDNA, even in males. Generally mantle and foot tissues are selected for clams (see as examples Kappner and Bieler, 2006; Plazzi and Passamonti, 2010; Chiesa et al., 2011).

\subsection{Mitochondrial DNA analyses}


Amplification of a $C O I$ gene fragment was achieved with a multiple set of primers: $C O I$ universal primers LCO1490: 5'-GGTCAACAAATCATAAAGATATTGG-3' and HCO2198: 5-

'TAAACTTCAGGGTGACCAAAAAATCA-3' (Folmer et al., 1994); degenerated COIF-ALT: 5'ACAAATCAYAARGAYATYGG-3' and COIR-ALT: 5' -TTCAGGRTGNCCRAARAAYCA-3' designed for Veneridae family (Kappner and Bieler, 2006; Mikkensen et al., 2006) and specific Manila clam primers designed by PRIMER 3 (Rozen and Skaletsky, 1998) named COI ALT LIV FW: 5'-AACMAATCATAAAGATATTGG-3' and COI ALT LIV RV: 5'-

AACTTCRGGRTGACCAAAAA-3' amplifying 704 bp of the COI gene fragment.

For those samples not amplifying with a single PCR, a nested approach was used with internal primers designed by PRIMER 3 (Rozen and Skaletsky, 1998) named COI FIL INT FW: 5'TTTTTCAWTTTGGGCTGGTY-3' and COI FIL INT RV 5'-CTCCCAACCCTATTGGRTCR-3', amplifying a 618 bp COI gene fragment.

A reaction volume of $50 \mu \mathrm{l}$ containing $1 \mathrm{U}$ of GoTaq Polymerase (Promega, Madison, WI, USA), $\mathrm{Mg} 2+1.5 \mathrm{mM}$ and dNTPs $0.2 \mathrm{mM}$, and10 pmol of each primer was used for each reaction. PCR touch down profile was set as follows for LCO1490/HCO2198 and COIF-ALT/COIR-ALT: 40 cycles of $30 \mathrm{~s}$ at $95^{\circ} \mathrm{C}, 45 \mathrm{~s}$ at $45^{\circ} \mathrm{C}$, and $60 \mathrm{~s}$ at $72^{\circ} \mathrm{C}$; after an initial $10 \mathrm{~min}$ denaturation step at $95^{\circ} \mathrm{C}$ and a final extension at $72^{\circ} \mathrm{C}$ for $10 \mathrm{~min}$ (Chiesa et al., 2011). For newly designed $\mathrm{COI} A L T$ $L I V F W / R V$ primers the following profile was performed: 35 cycles of $30 \mathrm{~s}$ at $94^{\circ} \mathrm{C}, 55 \mathrm{~s}$ at $48^{\circ} \mathrm{C}$, and $45 \mathrm{~s}$ at $72^{\circ} \mathrm{C}$; after an initial 3 min denaturation step at $94^{\circ} \mathrm{C}$ and a final extension at $72^{\circ} \mathrm{C}$ for 10 min. For newly designed COI FIL INT FWIRV primers the nested profile was performed as: 35 cycles of $30 \mathrm{~s}$ at $94^{\circ} \mathrm{C}, 50 \mathrm{~s}$ at $52^{\circ} \mathrm{C}$, and $40 \mathrm{~s}$ at $72^{\circ} \mathrm{C}$; after an initial 3 min denaturation step at $94^{\circ} \mathrm{C}$ and a final extension at $72^{\circ} \mathrm{C}$ for $5 \mathrm{~min}$.

Fragment sequencing was performed by MACROGEN Europe service (Amsterdam, the Netherlands). Multiple alignments of sense and antisense sequences were conducted using MEGA 6.06 (Tamura et al., 2013) and Sequencer 4.2 (Gene Code Corporation). The experimental 
sequences were aligned and compared with those of $R$. philippinarum obtained by GenBank from native Asian populations, and other species of the same genus including the Asian Ruditapes variegatus (synonym $R$. variegata, Sowerby 1852) and Ruditapes decussatus (Linnaeus, 1758), the latter is the native species of southern and western England, the Iberian Peninsula and the Mediterranean (Poppe and Goto, 1991). When obtaining sequences from GenBank, we followed the recommendations from Plazzi and Passamonti (2010) namely in retrieving female specimen data only due to the DUI, whenever this information was available. See Supplementary Table 1 for detailed Accession numbers and original sources.

Haplotype network analysis was performed through TCS v1.21 (Clement et al., 2000), with confidence threshold at $95 \%$ for Ruditapes genus sequences to test whether $R$. philippinarum haplotypes formed a single network separate to congeneric species (Hart and Sunday, 2007; Lucentini et al., 2011). Data were converted into a rdf file using DNA-alignment software and then a median-joining network (Bandelt et al., 1999) was constructed using Network 4.611 (both from Fluxus-Engineering: http://www.fluxus-engineering.com) for $R$. philippinarum haplotypes and outgroups.

The identification of variable and parsimony informative sites, the translation of nucleotide sequences, the pairwise genetic distances, the nucleotide base composition and the transition/transversion ratios were calculated using MEGA 6.06 (Tamura et al., 2013). Spatial or demographic expansion was estimated through Tajima's D neutrality test (Tajima, 1989) performed using DNAsp 5.0, assessing significance with 1000 permutations (Rossetti and Remis, 2012) and testing data for 4 different subsets: at large scale for the entire $R$. philippinarum pool, for the European pool, and separately for the Atlantic and for the Adriatic pools.

Statistical selection of best-fit models of nucleotide substitution was performed by means of jModelTest (Guindon and Gascuel, 2003; Darriba et al., 2012). This selection was based on 203 substitution schemes including scheme frequency, I and G rate variation, testing a total of 1624 
models. On the basis of these results, the Jukes-Cantor model was used to assess the evolutionary history among $R$. philippinarum, $R$. decussatus and other outgroups; Maximum Likelihood and Neighbour Joining methods were inferred in MEGA6.06 estimating standard error by a bootstrap procedure (1000 replicates). In particular, for the Maximum likelihood method a discrete Gamma distribution was used to model evolutionary rate differences among sites ( $\mathrm{G}$ categories $=4)$.

\section{Results}

Cytochrome oxidase I gene fragments were successfully sequenced and aligned unambiguously with those of GenBank for $491 \mathrm{bp}$. The final dataset comprised 465 sequences, 223 from this work. The overall number of mutations within the whole $R$. philippinarum dataset was 105 including both original and reference samples, and no insertion or deletion was observed. Among the European $R$. philippinarum sequences, 11 point mutations, 9 transitions (at positions 57, 96, 102, 126, 158, 321, $386,426,487$ ) and 2 transversions (positions 6 and 330) were identified.

174 haplotypes were identified including outgroups and 166 considering the whole $R$. philippinarum dataset (not shown).

The European R. philippinarum samples belonged to 13 haplotypes (RpCOI1-RpCOI13) whose GenBank Accession numbers are reported in Table 3. These haplotypes are closely related and grouped into a single network that is the only haplogroup emerging from these data (Fig. 2). The 13 haplotypes were differently represented on the whole dataset, $R p C O I 1, R p C O I 2$ and $R p C O I 3$ those showing the highest haplotype probability among European $R$. philippinarum haplotypes, respectively equal to 0.178 (RpCOI1), 0.150 (RpCOI2) and 0.229 (RpCOI3) (Fig. 2, Table 4). The other haplotypes, mainly those newly described, had a lower probability and were represented by only 1 or a few sequences, showing, consequently, lower weight values (Table 4). These differences in "consistency" of the COI haplotypes reflect their geographical distribution among the European countries. Observing haplotypes distribution, in fact, clearly emerged a complex pattern (Fig. 3, 
Supplementary Table 2), as 3 of them (RpCOI1, RpCOI2 and RpCOI4), were shared among Atlantic (UK, Spain, Portugal, France) and Adriatic populations (Italy). The remaining ones were identified only in the Atlantic (RpCOI3, RpCOI6, RpCOI7, RpCOI8) or in the Adriatic (RpCOI5, RpCOI 9, RpCOI10, RpCOI11, RpCOI12, RpCOI13) group.

The Tajima's Neutrality Test performed on the whole R. philippinarum sequences showed the occurrence of 105 segregating sites and a Tajima statistics test $\mathrm{D}$ value of -1.898 . Considering only European samples, Tajima's D value was 0.255 with 11 segregating sites. Restringing to fine scale, i.e. to either Atlantic or Adriatic samples, Tajima's D value was 0.965 (8 segregating sites) and -0.929 (10 segregating sites), respectively.

JModelTest identified JC as the best model (-InL = 320042.66). Bootstrap ML (Fig. 4) and NJ (not shown) phenograms performed with this model showed almost the same topology. Among $R$. philippinarum haplotypes, 3 main clusters can be identified as showed in Fig. 4. Cluster A (in blue) included mainly the Japanese, European and some Chinese haplotypes from both Genbank and from this work; clusters B (in green) and C (in red) included the majority of the Chinese haplotypes obtained from Genbank (Fig. 4).

All the 13 haplotypes identified in European populations grouped within the cluster A among different sub clusters (Fig. 5).

\section{Discussion}

The 13 COI haplotypes observed in the 20 European sampling sites were characterized by 3 common haplotypes (RpCOI1, 2, 3) connected to 10 derived and rare haplotypes (RpCOI4-13). Interestingly, haplotypes $R p C O I 1$ and $R p C O I 2$ were the most frequent and comprised almost $70 \%$ of the analyzed sequences, both from Atlantic and Adriatic populations. A similar pattern was previously observed for Portuguese, Spanish and Italian introduced populations by the direct sequencing of a 16SrDNA fragment (Chiesa et al., 2011; 2014). Moreover, the relatively high 
haplotype diversity observed in introduced populations reflect the genetic structure that has already been described for natural Chinese and Japanese populations (Mao et al., 2011; Kitada et al., 2013). A limited loss of genetic diversity in introduced populations was also indicated by microsatellite (Chiesa et al., 2011; 2016) and allozyme (Moraga, 1986) data.

The most common haplotypes identified in European samples (RpCOI1-3) have been previously observed in native populations. Specifically, $R p C O I 1$ corresponded to the haplotype $h 6$ (Kitada et al., 2013) from Japan; RpCOI2 to the haplotype $h 21$ (Kitada et al., 2013) from China Sea and Japan, and included also the samples of Qingdao, Nanao Bay, Rushan, Tianjin, Kagawa, Mikawa Bay, Tokyo Bay, Ariake Bay (Mao et al., 2011). The RpCOI3 corresponded to the haplotype $h 32$ (Kitada et al., 2013), from East China Sea and Japan, and also included the samples from Qingdao, Tianjin, Kagawa, Akkeshi, Mikawa Bay, Tokyo Bay, Ariake Bay, Notsuke Bay from the paper of Mao et al. (2011). The $R p C O I 5$ corresponded to the haplotype $h 53$ from Mikawa Bay and $R p C O I 8$ to the haplotype $h 58$, already identified in Japan (Kitada et al., 2013). The other 8 haplotypes were newly described, considering all the $R$. philippinarum sequences previously collected and registered in GenBank.

The $\mathrm{D}$ value of Tajima test calculated for the entire $R$. philippinarum dataset $(\mathrm{D}<0)$ showed the occurrence of many polymorphic sites (>100) and many haplotypes with low frequencies, indicating a population expansion mainly in the natural range of distribution. Yet when the Tajima test was performed only on European samples $(\mathrm{D}>0)$ it indicated the occurrence of multiple alleles, some at low $(<25 \%)$, but others at high frequencies $(>70 \%)$. This situation is frequently observed when a sudden population contraction or a founder effect occurs (Tajima, 1989). Data from Atlantic populations (positive D value) are consistent with balanced selection following the first Manila clam introduction in Europe. As for Adriatic populations, the negative value is consistent with a founder effect and additional introductions. This interpretation is also reinforced 
by the frequency data of different haplotypes in Atlantic and Adriatic areas obtained within this research.

The Maximum Likelihood radial tree performed on the whole Manila clam dataset showed the occurrence of 3 main clusters, as already described for the North-West Pacific Ocean by Mao et al. (2011): the lineage A included most of the Japanese populations, and some Chinese populations (specifically those from Kiaochow Bay, Rushan and Laizhou) whilst the lineages B and C were composed mainly of Chinese populations. As shown by the condensed tree in Fig. 5, all the 13 haplotypes observed in European populations belonged to cluster A and were distributed within 9 sub-clusters. The haplotype position in the radial tree does not support a recent evolution of the European haplotypes, including those newly described, which supports the hypothesis of an ancient evolution of the COI haplotypes of Manila clam. The occurrence of new haplotypes in the introduced populations, not previously described in native regions, may be due to a sampling bias among native and invaded communities. It is noteworthy that the most common haplotypes in European populations could be clearly identified within cluster A, mainly composed of Japanese, but also some Chinese haplotypes. Thus the COI data suggest the hypothesis that European populations of Manila clam could derive from Japanese and Chinese populations of the lineage A.

Reconstructing the routes of invasion within the European countries it is interesting to note that the 3 haplotypes with the highest probability- $R p C O I 1, R p C O I 2$ and $R p C O I 3$ - were occurring in all European populations, except for those of southern UK. These results confirm the hypothesis of a major human mediated introduction event commencing from a common pool within European countries. Portuguese (Ria de Aveiro, Óbidos and Ria Formosa lagoons, and Tagus and Sado estuaries) and Spanish (Galician coast) populations herein analyzed shared their haplotypes with France, Italy and UK, supporting the hypothesis of a strong founder effect also in the Iberian peninsula. However, especially in Portuguese populations, rare haplotypes with limited geographic 
distribution were observed, supporting the hypothesis of additional introduction events, probably intentionally and conducted by fishermen. The two English populations shared the same frequent haplotype - RpCOI4 (also observed in Spain and Northern Adriatic Sea with low frequencies) but the common European haplotypes $(R p C O I 1,2,3)$ are missing in these samples. This result may be explained by a bottleneck effect in the British populations. The naturalised British population is at the northern extremity of the species range which may not represent an optimal environment, even though Poole Harbour is shallow, warm and has lagonal characteristics (Humphreys, 2005). This hypothesis is also consistent with reported population densities which are significantly lower than those recorded in southern European sites such as on the Italian Adriatic coast (Breber, 2002; Humphreys et al., 2007; 2015). Isolated individuals as relics of otherwise unsuccessful spatfalls have also been observed in southern England (Humphreys et al., 2015). Together this could have determined the reduced haplotype diversity of naturalised populations. Although the samples from southern England were small, both Poole and Southampton populations were genetically similar, indicating that differences with southern populations are likely to be valid. As reported in the introduction section, the established population in Poole Harbour dates back to 1990 (Humphreys et al., 2015), whilst the naturalised Southampton population appeared later. Both natural dispersal from Poole (Herbert et al., 2012) and human-mediated introductions (Humphreys et al., 2015) are equally valid mechanisms for population establishment.

Finally, considering both genetic and informations from the literature, probable invasion routes for European populations of Manila clams can be formulated (Fig. 6). These routes are mainly human mediated, although for Southampton water a natural expansion cannot be excluded, as reported above. As described in literature, a major introduction event in Europe occurred from North America (Flassch and Leborgne, 1992), where Manila clam was previously introduced from Japan and placed overboard in Ladysmith Harbour (Canada) (Flassch and Leborgne, 1992). As also 
reported by Humphreys et al. (2015), Japanese clams were taken to the Hawaiian Islands (Bryan, 1919; Yap, 1977), then other Japanese clams reached the North American Pacific coast in the 1930s as an accidental introduction with stocks of Pacific oyster (Quayle, 1949). Clams from the Puget Sound were then separately introduced into France (1972-74) and then in UK (Conwy, Wales) (1980); from southern England the same pool was introduced in Northern Adriatic Sea (1983). In the early 1990s, clams from Northern Adriatic were frequently transported to Spain (M. Pellizzato, pers. comm.), and most probably from Spain to Portugal. Genetic data from this work confirmed the occurrence of a main founder effect in European populations. Moreover, the phylogenetic analysis confirmed that among the 5 haplotypes occurring in Europe and already described in the natural range of distribution, 3 are deriving from Japan ( $R p C O I 1, R p C O I 5, R p C O I 8)$ and 2 of them were already described both in Japan and China ( $R p C O I 2, R p C O I 3)$. The possible Japanese origin of Manila clam European populations is supported also by literature data on Perkinsus olseni and $P$. chesapeaki infections in European populations of $R$. philippinarum, as recently reviewed by Ruano et al. (2015). However, the occurrence of a high number of rare haplotypes with limited geographic distribution suggests additional introduction events not recorded previously. These introductions could have occurred intentionally for commercial exploitation without registration. In the Northern Adriatic Sea, for the first 2 years after introduction clam seeds for aquaculture activities were imported from England (Turolla, 2008) but then from Spain (TINAMENOR aquaculture facilities) and USA (California) during the middle and late 1990s (M. Pellizzato, pers. comm.). It is well known that over the period 1987 to 1991, Manila clam seed produced in Norway from a Scottish stock were massively exported for cultivation in Spain (Mortensen and Strand, 2000). Multiple introduction events could have occurred also due to the existence of mixed source populations, since Manila clams in Europe have been introduced from non-native populations, already manipulated for commercial purposes. 
Finally, as the European Atlantic coast is subjected to introduction of oyster seed for culture (mainly Crassostrea gigas), both from European and non-European countries, accidental species introduction is possible (Wolff and Reise, 2002) as previously documented for Manila clams in North America (Quayle, 1949).

\section{1. Conclusions}

This paper provides the first genetic comparison of Manila clam populations introduced in to Europe with native clams. The direct sequencing of a $\mathrm{COI}$ gene fragment has provided data supporting a strong founder effect of European populations, with 3 main haplotypes occurring at high frequencies.

However, high haplotype diversity due to the occurrence of 10 rare haplotypes, suggests (i) additional introductions - probably intentionally conducted- following the main event, and (ii) a limited loss of genetic diversity in introduced populations.

Establishing geographic origins and the diversity and structure of exploited populations has significant implications for the management and traceability of clam stocks. The occurrence of illegal clam exploitation in moderate and highly polluted environments could represent a serious risk for human consumption. Thus, knowledge of geographic origin is fundamental to product traceability within the clam market. The genetic profile of clam populations could be a useful tool to trace origin of stocks, preventing fraud concerning clam products and avoiding mislabeling in European countries. Moreover, the genetic data can help to understand the structure of exploited populations, especially in terms of their variability and resilience to exploitation and selection driven by aquaculture activities. The maintenance of high genetic diversity in exploited clam populations is necessary to ensure the survival of the resource over time and the preservation of population's fitness. In fact, the high reproductive capability, growth rate and the capacity to respond to environmental changes are strongly influenced by levels of genetic diversity. 
395 In conclusion, the genetic resources of Manila clam in Europe should be furtherly investigated and 396 monitored to ensure its sustainable exploitation.

397 
399 The research was funded by own funds of Molecular Sciences and Nanosystems Dept. (Venice) and 400 Life Sciences Dept (Parma) and by the Spin off "Gen Tech" of the University of Parma. Thanks are 401 also due for the financial support to CESAM (UID/AMB/50017), to FCT/MEC through national 402 funds, and the co-funding by the FEDER, within the PT2020 Partnership Agreement and Compete 403 2020. Stefania Chiesa and Rosa Freitas benefited from Post Doctoral grants 404 (SFRH/BPD/91923/2012 and SFRH/BPD/92258/2013) given by the National Funds through the 405 Portuguese Science Foundation (FCT), supported by European Social Fund, "Programa Operacional 406 Capital Humano (POCH)" and European Community.

407 Authors would like to thank Dr. Marina Vaghi (Parma University, Italy) for her help with 408 laboratory procedures and those who help with samples collection: Dr. Daniele Nizzoli (Parma 409 University, Italy) for Goro Lagoon, Dr. Francisco Ruano (IPMA, Portugal) for Sado Estuary, Prof. 410 Sergio Leandro (ESTM, Instituto Politécnico de Leiria, Portugal) for Óbidos lagoon, Sr. Augusto da Paz (Formosa - Cooperativa de viveirista da Ria Formosa, Portugal) for Algarve, and professional fishermen and their committee for Arcachon Bay.

414 Faculty of Sciences, Lisbon University) for their helpful suggestions to improve the text.

\section{References}

An, H.S., Park, K.J., Cho, K.C., Han, H.S., Myeong J.I., 2012. Genetic structure of Korean populations of the clam Ruditapes philippinarum inferred from microsatellite marker analysis. Biochem. Syst. Ecol. 44, 186-195.

Astorga., M.P., 2008. Estado actual del uso de marcadores moleculares en moluscos bivalvos de importancia para la acuicultura, in: Lovatelli, A., Farias, A., Uriarte I. (Eds), Estado Actual Del Cultivo y Manejo de Moluscos Bivalvos y su Proyección Futura: Factores Que Afectan 
Su Sustentabilidad en America Latina. Actas de Pesca de la FAO. N 12, FAO, Rome, pp. $277-287$.

Astorga, M.P., 2014. Genetic considerations for mollusk production in aquaculture: current state of knowledge. Front. Genet. 5, 435. DOI: 10.3389/fgene.2014.00435.

Bald, J., Sinquin, A., Borja, A., Caill-Milly, N., Duclercq, B., Dang, C., de Montadouin, X., 2009. A system dynamics model for the management of the Manila clam, Ruditapes philippinarum (Adams and Reeve, 1850) in the Bay of Arcachon (France). Ecol. Model. 220, 2828-2837.

Bandelt, H.J., Forster, P., Röhl A., 1999. Median-joining networks for inferring intraspecific phylogenies. Mol. Biol. Evol. 16, 37-48.

Bartoli, M., Castaldelli, G., Nizzoli, D., Fano, E.A.,Viaroli, P.G. Manila clam introduction in the Sacca di Goro Lagoon (Northern Italy): ecological implications. Bull. Fish. Res. Ag. Jap., accepted, in press.

Bidegain, G., Juanes, J.S., 2013. Does expansion of the introduced Manila clam Ruditapes philippinarum cause competitive displacement of the European native clam Ruditapes decussatus? J. Exp. Mar. Biol. Ecol. 445, 44-52.

Boscolo Brusà R., Cacciatore, F., Ponis, E., Molin, E., Delaney E., 2013. Clam culture in the Venice lagoon: stock assessment of Manila clam (Venerupis philippinarum) populations at a nursery site and management proposals to increase clam farming sustainability. Aquat. Living Resour. 26, 1-10

Breber, P., 1985. L'introduzione e l'allevamento in Italia dell'arsella del Pacifico, Tapes semidecussatus Reeve (Bivalvia; Veneridae). Oebalia XI-2, 675-680.

Breber, P., 2002. Introduction and acclimatisation of the Pacific carpet clam Tapes philippinarum, to Italian waters. In: Leppakoski, E., Gollasch, S., Olenin, S. (Eds), Invasive aquatic species of Europe. Distribution, impacts and management. Kluwer Academic, Dordrecht, pp. 120126. 
Bryan, A., 1919. A Hawaiian form of Tapes philippinarum. Nautilus 32,124-125.

Cao, L., Kenchington, E., Zouros, E., 2004. Differential segregation patterns of sperm mitochondria in embryos of the blue mussel (Mytilus edulis). Genetics 166, 883-894.

Chainho, P., 2014. Portuguese report. In: Report of the Working Group on Introduction and Transfers of Marine Organisms (WGITMO), 19-21 March, 2014, Palanga, Lithuania. ICES CM 2014/ACOM: 32, 259 pp.

Chainho, P., Fernandes, A., Amorim, A., et al., 2015. Non-indigenous species in Portuguese coastal areas, coastal lagoons, estuaries, and islands. Estuarine, Coastal and Shelf Science, DOI: 10.1016/j.ecss.2015.06.019.

Chen, J., Li, Q., Kong, L., Yu, H., 2011. How DNA barcodes complement taxonomy and explore species diversity: the case study of a poorly understood marine fauna. PLoS One 6(6), E21326.

Chiesa, S., Nonnis Marzano, F., Minervini, G., De Lucrezia, D., Baccarani, G., Bordignon, G., Poli, I., Ravagnan, G., Argese, E., 2011. The invasive Manila clam Ruditapes philippinarum (Adams and Reeve, 1850) in Northern Adriatic Sea: population genetics assessed by an integrated molecular approach. Fish. Res. 110, 259-267.

Chiesa, S., Lucentini, L., Freitas, R., Nonnis Marzano, N., Minello, F., Ferrari, C., Filonzi, L., Figueira, E., Breda, S., Baccarani, G., Argese E., 2014. Genetic diversity of introduced Manila clam Ruditapes philippinarum populations inferred by $16 S$ rDNA. Biochem. Syst. Ecol. 57, 52-59.

Chiesa, S., Lucentini, L., Freitas, R., Nonnis Marzano, N., Ferrari, C., Filonzi, L., Breda, S., Minello, F., Figueira E., Argese, E., 2016. Null alleles of Microsatellites for Manila clam Ruditapes philippinarum. Anim. Genet. DOI: 10.1111/age.12382. 
Chiesa, S., Lucentini, L., Freitas, R., Nonnis Marzano, F., Breda, S., Figueira, E., Caill-Milly, N., Herbert, R., Soares, A.M.V.M., Argese, E. Mapping the stranger: genetic diversity of Manila clam in European coastal lagoons. Bull. Fish. Res. Ag. Jap., accepted, in press.

Clement, M., Posada, D., Crandall, K.A., 2000. TCS: a computer program to estimate gene genealogies. Mol. Ecol. 9, 1657-1659.

Darriba, D., Taboada, G.L., Doallo, R., Posada, D., 2012. jModelTest 2: more models, new heuristics and parallel computing. Nat. Methods 9, 772-772.

Flassch, J.P., Leborgne Y., 1992. Introduction in Europe, from 1972 to 1980, of the Japanese Manila clam (Tapes philippinarum) and the effects on aquaculture production and natural settlement. ICES mar. Sei. Symp. 194, 92-96.

Folmer,O., Black, M., Hoeh, W., Lutz, R., Vrijenhoek, R., 1994. DNA primers for amplification of mitochondrial cytochrome c oxidase subunit I from diverse metazoan invertebrates. Mol. Mar. Biol. Biotechnol. 5, 294-299

Gosling, E., 2003. Bivalve Molluscs: Biology, Ecology and Culture. Fishing News Books, Blackwell Publishing, Oxford.

Gaspar, M.B., 2010. Distribuição, abundância e estrutura demográfica da amêijoa Japonesa (Ruditapes philippinarum) no Rio Tejo. Relatório do IPIMAR, 6 pp.

Guindon, S., Gascuel O., 2003. A simple, fast and accurate method to estimate large phylogenies by maximum-likelihood. Syst. Biol. 52, 696-704.

Hart, M.W., Sunday, J., 2007. Things fall apart: biological species form unconnected parsimony networks. Biol. Lett. 3, 509-512.

Hartl, D. L. \& A. G. Clark, 1997. Principles of population genetics. Sinauer Associates, Sunderland, Massachusetts. 
Herbert, R. J.H., Willis, J., Jones, E., Ross, K., Huebner, R., Humphreys, J., Jensen, A., Baugh, J., 2012. Invasion in tidal zones on complex coastlines: modelling larvae of the non-native Manila clam, Ruditapes philippinarum, in the UK. J. Biogeog. 39, 585-599.

Holland, B.S., 2000. Genetics of marine bioinvasions. Hydrobiologia 420, 63-71.

Humphreys, J., 2005. Salinity and tides in Poole Harbour: Estuary or Lagoon? In: Humphreys, J., May, V. (Eds.), The Ecology of Poole Harbour. Proceedings in Marine Science (7), Elsevier, Amsterdam, pp 35-47.

Humphreys, J., Caldow, R.W.G., McGrorty, S., West, A.D., Jensen A.C., 2007. Population dynamics of naturalised Manila clams in British coastal waters. Mar. Biol. 151, 2255-2270.

Humphreys, J., Harris, M.R.C., Herbert, R.J.H., Farrell, P., Jensen, A., Cragg S.M., 2015. Introduction, dispersal and naturalization of the Manila clam Ruditapes philippinarum in British estuaries, 1980-2010. J. Mar. Biol. Assoc. UK DOI:10.1017/S0025315415000132.

Jensen, A.C., Humphreys, J., Caldow, R.W.G., Grisley, C., Dyrynda P.E.J., 2004. Naturalisation of the Manila clam (Tapes philippinarum), an alien species, and establishment of a clam fishery within Poole Harbour, Dorset. J. Mar. Biol. Assoc. UK 84, 1069-1073

Kappner, I., Bieler, R., 2006. Phylogeny of Venus clams (Bivalvia: Venerinae) as inferred from nuclear and mitochondrial gene sequences. Mol. Phylogenet. Evol. 40, 317-331.

Kitada, S., Fujiake, C., Asakura, Y., Yuki, H., Nakajima, K., Vargas, K.M., Kawashima, S., Hamasaki, K., Kishino H., 2013. Molecular and morphological evidence of hybridization between native Ruditapes philippinarum and the introduced Ruditapes form in Japan. Cons. Genet. 14, 717-733.

Liu, X., Bao, Z., Hu, J., Wang, S., Zhan, A., Liu, H., Fang, J..,Wang R., 2007. AFLP analysis revealed differences in genetic diversity of four natural populations of Manila clam (Ruditapes philippinarum) in China. Acta Oceanol. Sin. 26, 150-158. 
Lucentini, L., Rebora, M., Puletti, M.E., Gigliarelli, L., Fontaneto, D., Gaino, E., Panara, F., 2011. Geographical and seasonal evidence of cryptic diversity in the Baetis rhodani complex (Ephemeroptera, Baetidae) revealed by means of DNA taxonomy. Hydrobiologia 673, $215-228$.

Magoon, C., Vining, R., 1981. Introduction to shellfish aquaculture in the Puget Sound Region. Department of Natural Resources, Olympia, WA.

Mao, Y.L., Gao, T.X., Yanagimoto, T., Xiao Y.S., 2011. Molecular phylogeography of Ruditapes philippinarum in the Northwestern Pacific Ocean based on COI gene. J. Exp. Mar. Biol. Ecol. 407, 171-181.

Mayr, E., 1963. Animal Species and Evolution. Harvard University Press. Cambridge, Massachusetts

Mikkelsen, P.M., Bieler, R., Kappner, I., Rawlings, T., 2006. Phylogeny of Veneroidea (Mollusca: Bivalvia) based on morphology and molecules. Zool. J. Linn. Soc. Lond. 148, 439-521.

Mortensen, S.H., Stand, Ø., 2000. Releases and recaptures of Manila clams (Ruditapes philippinarum) introduced to Norway. Sarsia 85, 87-91.

Moraga, D., 1986. Polymorphisme génétique de populations cultivées de la palourde du Pacifique Tapes philippinarum. C. R. Acad. Sc. Paris. 17, 621-624.

Mura, L., Cossu, P., Cannas, A., Scarpa, F., Sanna, D., Dedola, G.L., Floris, R., Lai, T., Cristo, B., Curini-Galletti, M., Fois, N., Casu, M., 2012. Genetic variability in the Sardinian population of the Manila clam, Ruditapes philippinarum. Biochem. Syst. Ecol. 41, 74-82.

Nie, H.T., Niu, H.B., Zhao, L.Q., Yang, F., Yan, X.W., Zhang G.F., 2015. Genetic diversity and structure of Manila clam (Ruditapes philippinarum) populations from Liaodong peninsula revealed by SSR markers. Biochem. Syst. Ecol. 59, 116-125. 
Yáñez, J.M., Newman, S., Houston, R.D., 2015. Genomics in aquaculture to better understand species biology and accelerate genetic progress. Front. Genet. DOI:10.3389/fgene.2015.00128

Yap, W.G.,1977. Population biology of the Japanese little-neck clam, Tapes philippinarum in Kaneohe Bay, Oahu, Hawaiian Islands. Pac. Science 31, 223-244.

Passamonti, M., Scali, V., 2001. Gender-associated mitochondrial DNA heteroplasmy in the venerid clam Tapes philippinarum (Mollusca: Biv-alvia). Curr. Gen. 39, 117-124.

Pellizzato, M., 1990. Acclimatization of the Tapes philippinarum species and first experimental rearing basins in Italy, in: AA. VV. (Eds.), Tapes philippinarum - Biologia e Sperimentazione. E.S.A.V., Veneto Region, pp 159-170.

Perez-Camacho, A., Cuna M., 1985. First data on raft culture of Manila clam in the Ria de Arosa. ICES Conferences \& Meetings, F: 43, 22 pp.

Plazzi, F., Passamonti, M., 2010. Towards a molecular phylogeny of mollusks: bivalves' early evolution as revealed by mitochondrial genes. Mol. Phylogenet. Evol. 57, 641-657.

Poppe, G.T., Goto, Y., 1991. European seashells. Vol 1 (Polyplacophora, Caudofoveata, Solenogastra, Gastropoda). Verlag Christa Hemmen, Wiesbaden.

Quayle, D.B.,1949. Movements in Venerupis (Paphia) pullastra (Montagu). Proc. Malacol. Soc. Lond. 28, 31-37.

Robert, R., Deltreil, J.P., 1990. Élevage de la palourde japonaise Ruditapes philippinarum dans le Bassin d'Arcachon. Rapport Interne Ifremer. RIDRV-90.40-RA, Arcachon.

Robert, R., Sánchez, J.L., Pérez-Parallé, Luz, Ponis, E., Kamermans, P., O' Mahoney, M. 2013. A glimpse on the mollusc industry in Europe. Aquac. Eur. 38, 5-11. 
Roman, J., Darling, J.A., 2007. Paradox lost: genetic diversity and the success of aquatic invasions. Trends Ecol. Evol. 22, 454-464.

Rossetti,N., Remis, M.I. 2012. Spatial genetic structure and mitochondrial DNA phylogeography of Argentinean populations of the grasshopper Dichroplus elongatus. PlosOne 7 (7) e40807

Rozen, S., Skaletsky, H.J., 1998. Primer3. Code available at http://wwwgenome.wi.mit.edu/genome_software/other/primer3.html.

Ruano, F., Sobral, D.V., 2000. Marine non-indigenous species current situation in Portugal. Pp. 58e63, In: Rodrigues, L., Reino, L., Godinho, L.O., Freitas, H. (Eds.), Proceedings of the 1st Symposium on Non-indigenous Species: Introduction, Causes and Consequences. Liga para a Protecção da Natureza, Lisbon.

Ruano, F., Batista F.M., Arcangeli G., 2015. Perkinsosis in the clams Ruditapes decussatus and $R$. philippinarum in the Northeastern Atlantic and Mediterranean Sea: A review. J. Invertebr. Pathol. DOI:10.1016/j.jip.2015.07.015.

Sanchez, F., Caill-Milly, N., Lissardy, M., Bru, N., 2014. Campagne d'évaluation de stock de palourdes du bassin d'Arcachon. Année 2014. http://archimer.ifremer.fr/doc/00233/34383/

Sekine, Y., Yamakawa, H., Takazawa, S., Lin, Y., Toba, M., 2006. Geographic variation of the COXI gene of the short-neck clam Ruditapes philippinarum in coastal regions of Japan and China. Venus 65, 229-240 (in Japanese).

Tajima, F., 1989. Statistical methods to test for nucleotide mutation hypothesis by DNA polymorphism. Genetics $123,585-595$. 
Tamura, K., Stecher, G., Peterson, D., Filipski, A., Kumar, S. 2013. MEGA 6: Molecular Evolutionary Genetics Analysis version 6.0. Mol. Biol. Evol. 30, 2725-2729.

Taylor, D.R., Keller, S.R., 2007. Historical range expansion determines the phylogenetic diversity introduced during contemporary species invasion. Evolution 61, 334-345.

Turolla, E., 2008. La venericoltura in Italia, in: Lovatelli, A., Farías, A., Uriarte, I. (Eds.), Estado actual del cultivo y manejo de moluscos bivalvos y su proyección futura: factores que afectan su sustentabilidad en América Latina. Taller Técnico Regional de la FAO, FAO, Rome, pp. 177-188.

Vargas, K., Asakura, Y., Ikeda, M., Taniguchi, N., Obata, Y., Hamasaki, K., Tsuchiya, K., Kitada S., 2008. Allozyme variation of littleneck clam Ruditapes philippinarum and genetic mixture analysis of foreign clams in Ariake Sea and Shiranui Sea off Kyushu Island. Japan Fish. Sci. $74,533-543$.

Velez, C., Figueira, E., Soares, A., Freitas, R., 2015a. Spatial distribution and bioaccumulation patterns in three clam populations from a low contaminated ecosystem. Estuar. Coast. Shelf. S. $155,114-125$.

Velez, C., Leandro, S., Figueira, E., Soares A.M.V.M., Freitas, R., 2015b. Biochemical performance of native and introduced clam species living in sympatry: The role of elements accumulation and partitioning. Mar. Environ. Res. 109, 81-94.

Zouros, E., Ball, A.O., Saavedra, C., Freeman, K.R., 1994. Mitochondrial DNA inheritance. Nature 368,818 .

Wolff, W.J., Reise, K., 2002. Oyster as vector for the introduction of alien species into Northern and Western European coastal waters, in: Leppäkoski, E., Gollasch, S., Olenin, S. (Eds.), 
Invasive Aquatic Species of Europe. Distribution, Impacts and Management. SpringerScience + Business Media, B.V., New York.

608

609 
611 Table 1

612 First introductions (authorized or unauthorized) of Manila clam R. philippinarum in Europe.

\begin{tabular}{lll}
\hline \multicolumn{1}{c}{ Country } & \multicolumn{1}{c}{ Year } & \multicolumn{1}{c}{ Reference source } \\
\hline France & 1972 (authorized) & $\begin{array}{l}\text { Robert and Deltreil, 1990; Flassch and Laborgne, } \\
1992\end{array}$ \\
$\begin{array}{l}\text { United } \\
\text { Kingdom }\end{array}$ & 1980 (authorized) & $\begin{array}{l}\text { Humphreys et al., 2015 } \\
\text { Italy }\end{array}$ \\
Spain & 1983 (authorized) & Breber, 1985 \\
& $\begin{array}{l}1983-85 \\
\text { (unauthorized) }\end{array}$ & Perez-Camacho and Cuna, 1985 \\
Portugal & 1984 (unauthorized) & Ruano and Sobral, 2000 \\
\hline
\end{tabular}

613

614 
616 Manila clam sampling sites. Estuarine environments herein analyzed are provided with Country, 617 Estuarine system, Site, Acronyms and number of analyzed specimen. The ${ }^{*}$ symbol indicates the 618 populations already analyzed by $16 S$ rDNA (see Chiesa et al., 2014).

619

\begin{tabular}{|c|c|c|c|c|}
\hline Country & Estuarine System & Site & Acronym & $\mathbf{N}$ \\
\hline Italy & Marano Lagoon* & Site 1 & UD & 16 \\
\hline Italy & Marano Lagoon* & Site 2 & GR & 17 \\
\hline Italy & Venice Lagoon* & Busa & AV & 10 \\
\hline Italy & Venice Lagoon* & Palude di Monte & $\mathrm{BV}$ & 16 \\
\hline Italy & Venice Lagoon* & Fusina & $\mathrm{FV}$ & 9 \\
\hline Italy & Po River Delta* & Marinetta & MA & 10 \\
\hline Italy & Po River Delta* & Caleri & $\mathrm{CA}$ & 11 \\
\hline Italy & $\begin{array}{l}\text { Sacca degli } \\
\text { Scardovari* }\end{array}$ & Scardovari & $\mathrm{SC}$ & 11 \\
\hline Italy & Sacca di Goro & Goro & GO & 11 \\
\hline Portugal & Ria de Aveiro Lagoon* & Murtosa & MU & 7 \\
\hline Portugal & Ria de Aveiro Lagoon* & Esteiro Rio Boco & ST & 8 \\
\hline Portugal & Ria de Aveiro Lagoon* & Costa Nova & $\mathrm{CN}$ & 7 \\
\hline Portugal & Óbidos lagoon & Obidos lagoon & OB & 20 \\
\hline Portugal & Ria Formosa & Ria Formosa & $\mathrm{AL}$ & 2 \\
\hline Portugal & Tagus estuary & Tagus estuary & TA & 11 \\
\hline Portugal & Sado estuary & Sado estuary & $\mathrm{SD}$ & 16 \\
\hline Spain & Galician coast* & La Coruna & ES & 10 \\
\hline France & Arcachon Bay & Arcachon Bay & $\mathrm{AR}$ & 15 \\
\hline UK & Poole Harbour & Poole Harbour & $\mathrm{PH}$ & 6 \\
\hline UK & Southampton & Southampton & $\mathrm{SH}$ & 10 \\
\hline
\end{tabular}


622 COI haplotypes of $R$. philippinarum deposited in GenBank. Haplotype acronym and Accession 623 numbers are provided.

\begin{tabular}{ll}
\hline Haplotype Acronym & Genbank A.N. \\
\hline$R p C O I 1$ & KU252867 \\
$R p C O I 2$ & KU252866 \\
$R p C O I 3$ & KU252868 \\
$R p C O I 4$ & KU252869 \\
$R p C O I 5$ & KU252870 \\
$R p C O I 6$ & KU252871 \\
$R p C O I 7$ & KU252872 \\
$R p C O I 8$ & KU252873 \\
$R p C O I 9$ & KU252874 \\
$R p C O I 10$ & KU252875 \\
$R p C O I 11$ & KU252876 \\
$R p C O I 12$ & KU252877 \\
$R p C O I 13$ & KU252878 \\
\hline
\end{tabular}


627 Results of Minimum Spanning Network analysis. The probability weight is shown for each 628 haplotype.

\begin{tabular}{lll}
\hline Haplotype Acronym & Haplogroup & Weight \\
\hline$R p C O I 1$ & $\mathrm{H} 1$ & 0.178 \\
$R p C O I 2$ & $\mathrm{H} 1$ & 0.150 \\
$R p C O I 3$ & $\mathrm{H} 1$ & 0.229 \\
$R p C O I 4$ & $\mathrm{H} 1$ & 0.024 \\
$R p C O I 5$ & $\mathrm{H} 1$ & 0.001 \\
$R p C O I 6$ & $\mathrm{H} 1$ & 0.137 \\
$R p C O I 7$ & $\mathrm{H} 1$ & 0.004 \\
$R p C O I 8$ & $\mathrm{H} 1$ & 0.001 \\
$R p C O I 9$ & $\mathrm{H} 1$ & 0.001 \\
$R p C O I 10$ & $\mathrm{H} 1$ & 0.003 \\
$R p C O I 11$ & $\mathrm{H} 1$ & 0.001 \\
$R p C O I 12$ & $\mathrm{H} 1$ & 0.134 \\
$R p C O I 13$ & $\mathrm{H} 1$ & 0.134 \\
\hline
\end{tabular}


630

631

632

633

634

635

636 637 2011).

638

639

640

641

642

643

644

645

646

647

648

649

\section{Figure Captions:}

Fig. 1. Collection sites of Manila clam in Atlantic and Adriatic European coastlines (Modified from d-maps.com)

Fig. 2. Median-joining network of the 13 COI haplotypes for European samples of $R$.

philippinarum. The most representative haplotype of the unique haplogroup is reported in a square instead the other haplotypes are reported in oval. The size of the ovals is proportional to the consistency of haplotypes. Small dots report base substitutions (see as example Lucentini et al.,

Fig. 3. Geographic distribution of the 13 R. philippinarum haplotypes for each analyzed population. The underlined haplotypes $R p C O I 1, R p C O I 2$, RpCOI4 are shared among Atlantic and Adriatic populations.

Fig. 4. Maximum Likelihood (ML) radial tree of R. philippinarum COI haplotypes. Japanese Cluster A (blue) and Chinese clusters B (green) and C (red) are shown.

Fig. 5. Maximum Likelihood (ML) radial condensed tree of COI cluster A. European haplotypes are indicated by black circles. Japanese Cluster A (blue) and Chinese clusters B (green) and C (red) are shown.

Fig. 6. Manila clam routes of invasion in Europe, inferred from bibliographic information, expert opinion and $C O I$ data. 


\section{Supplementary Table 1}

651 Selected COI gene sequences used in the phylogenetic analyses. For each species the GenBank 652 accession number and the original sources are reported.

$\begin{array}{lll}\text { species } & \text { GenBank A.N. } & \text { Original source } \\ \text { R. philippinarum } & \text { AB694757-AB694884 } & \text { Kitada et al., 2013 } \\ & \text { JN054502-JN544632 } & \text { Mao et al., 2011 } \\ & \text { AB244374-AB244412 } & \text { Sekine et al., 2006 } \\ & \text { HQ703306-HQ703311 } & \text { Chen et al., 2011 } \\ \text { R. variegatus } & \text { AB694885-AB694891 } & \text { Kitada et al., 2013 } \\ \boldsymbol{R} . \text { decussata } & \text { DQ458492 } & \text { Kappner and Bieler, 2006 }\end{array}$




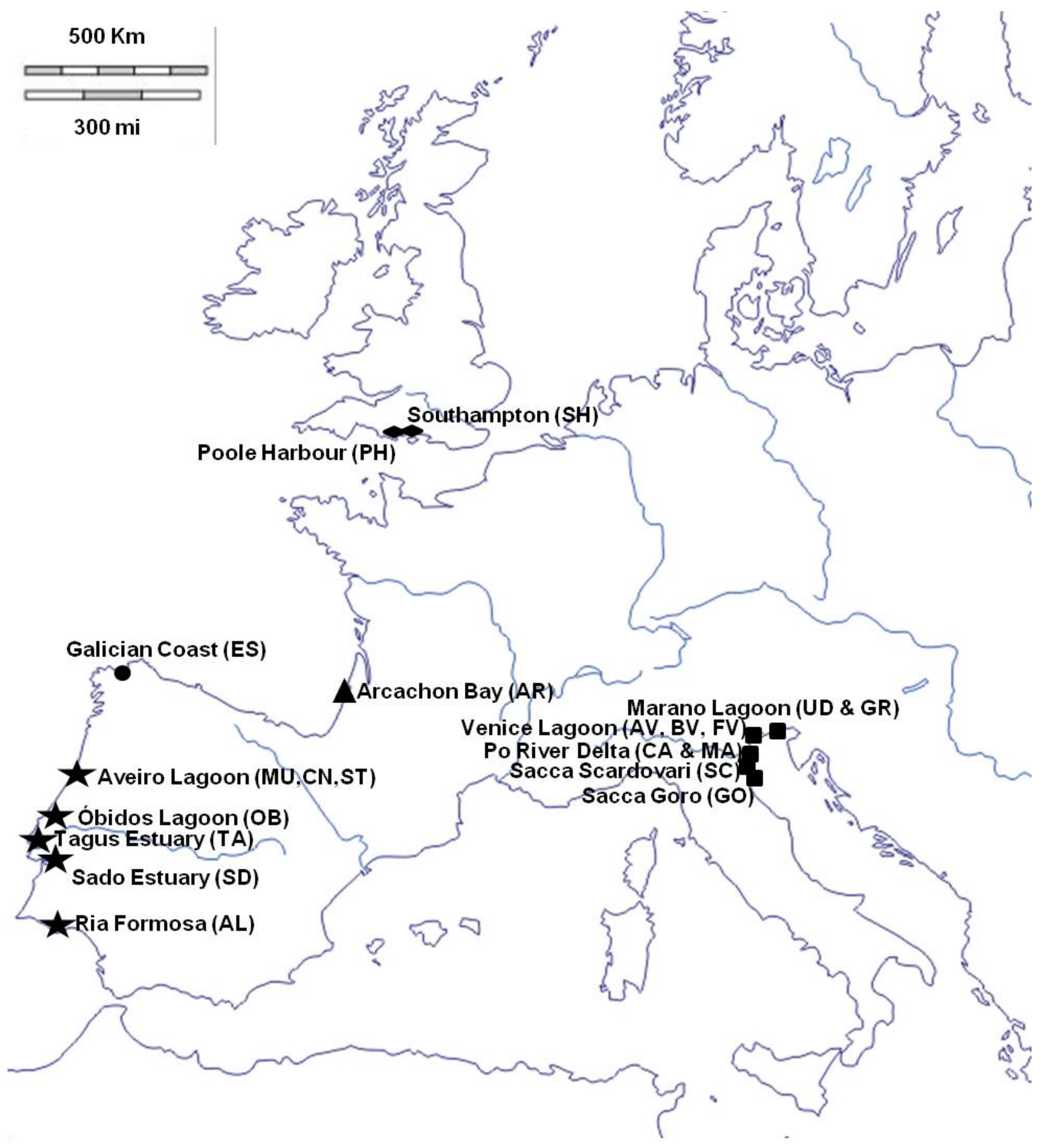


658 Figure 2

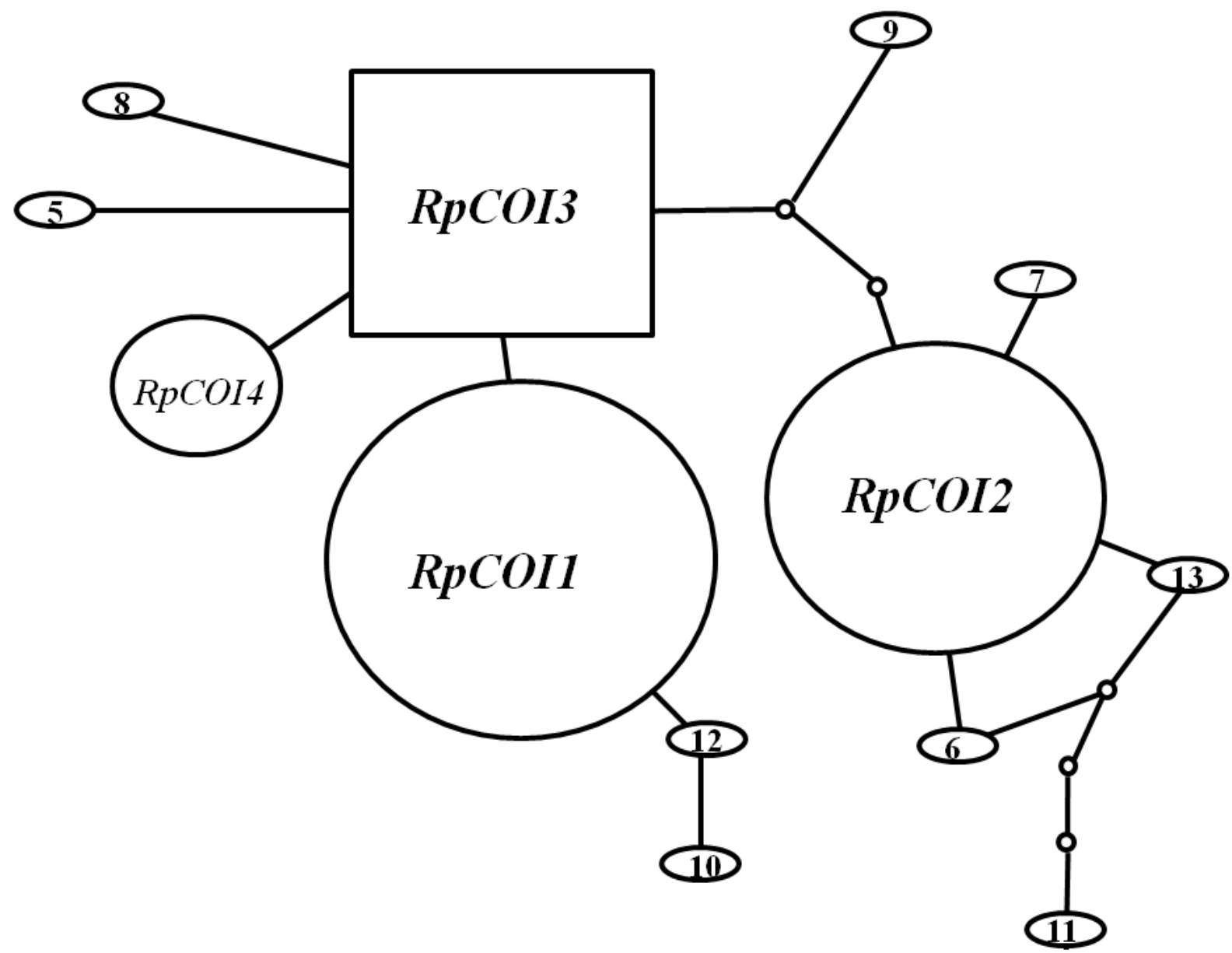




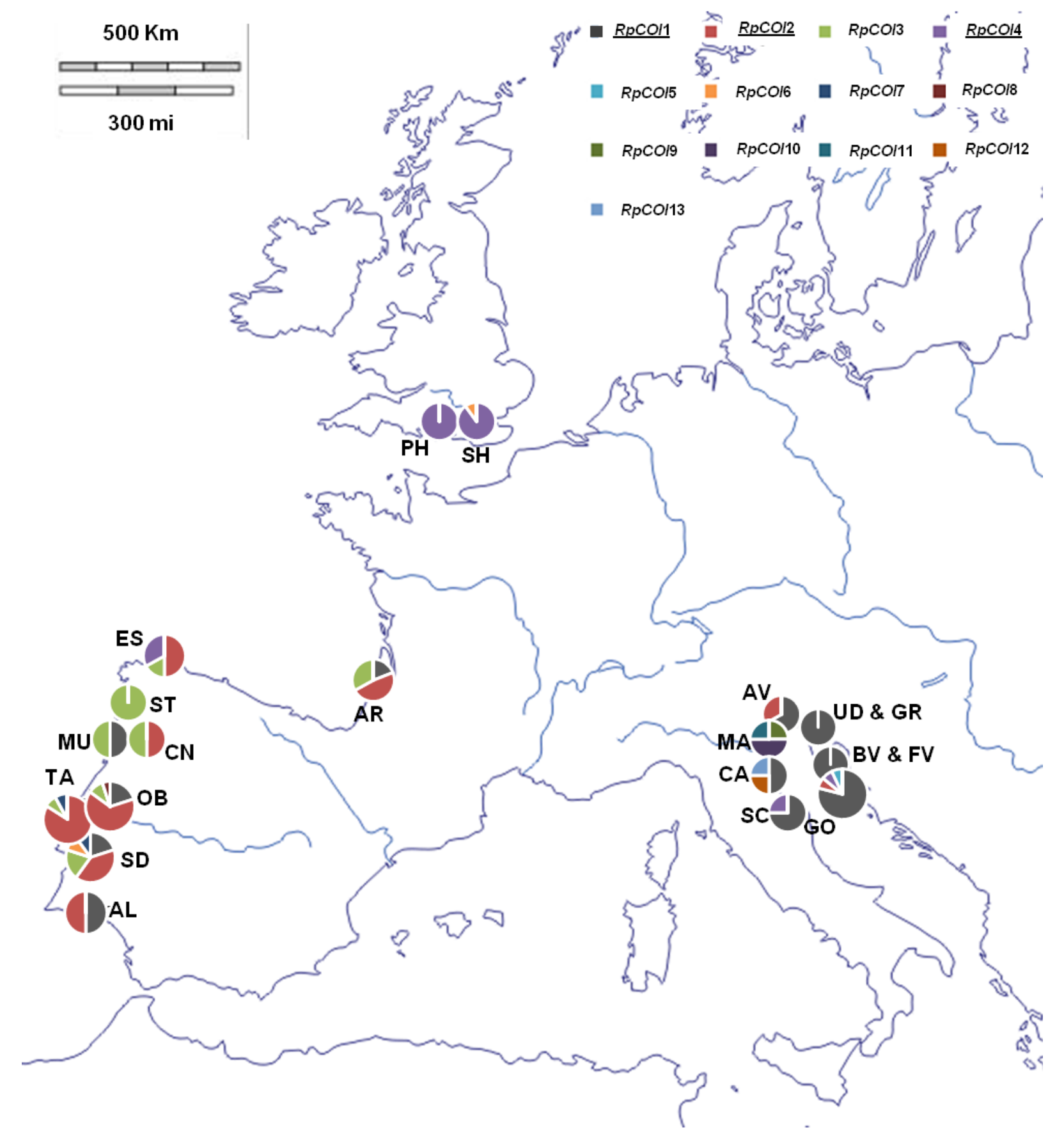




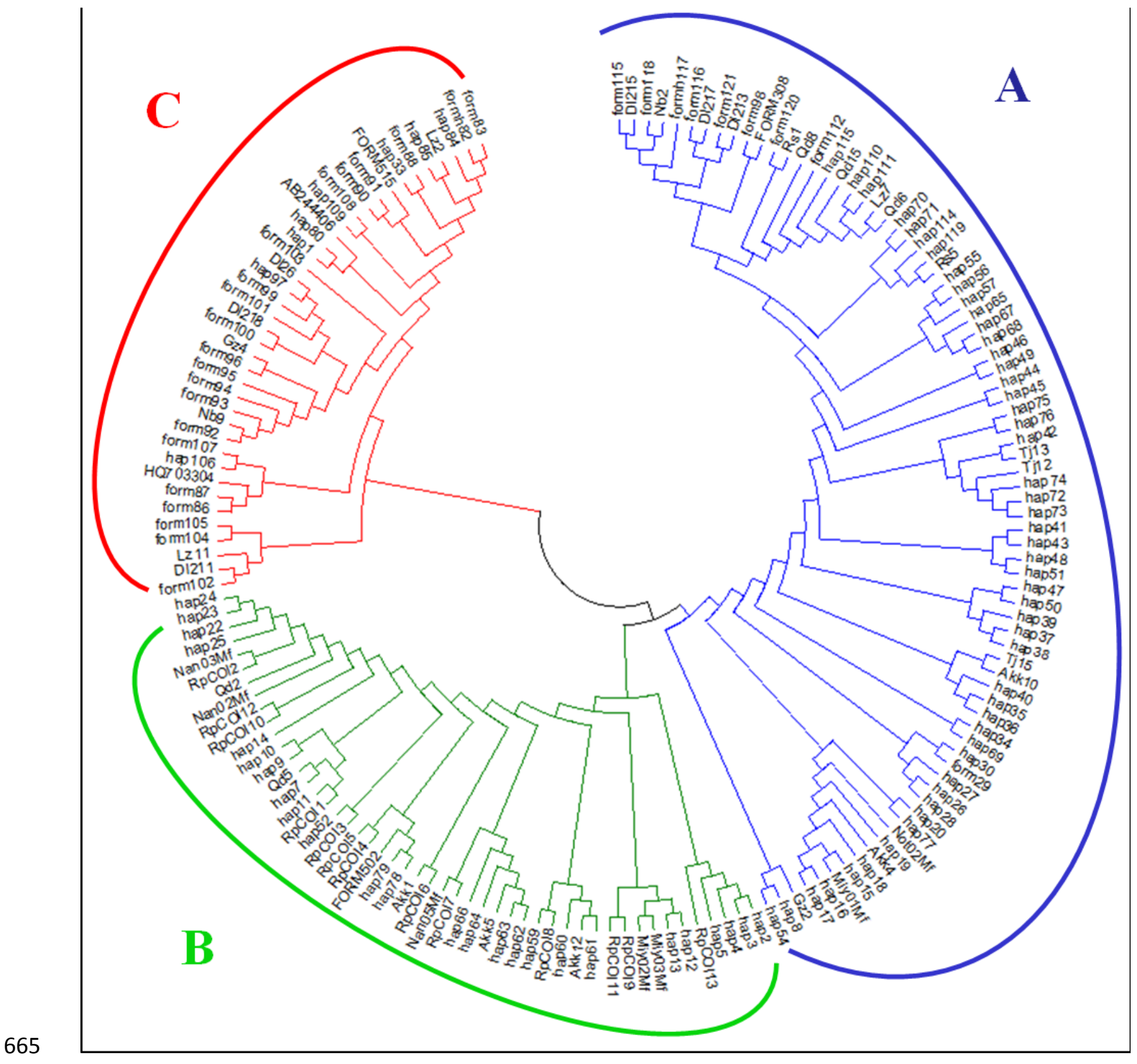




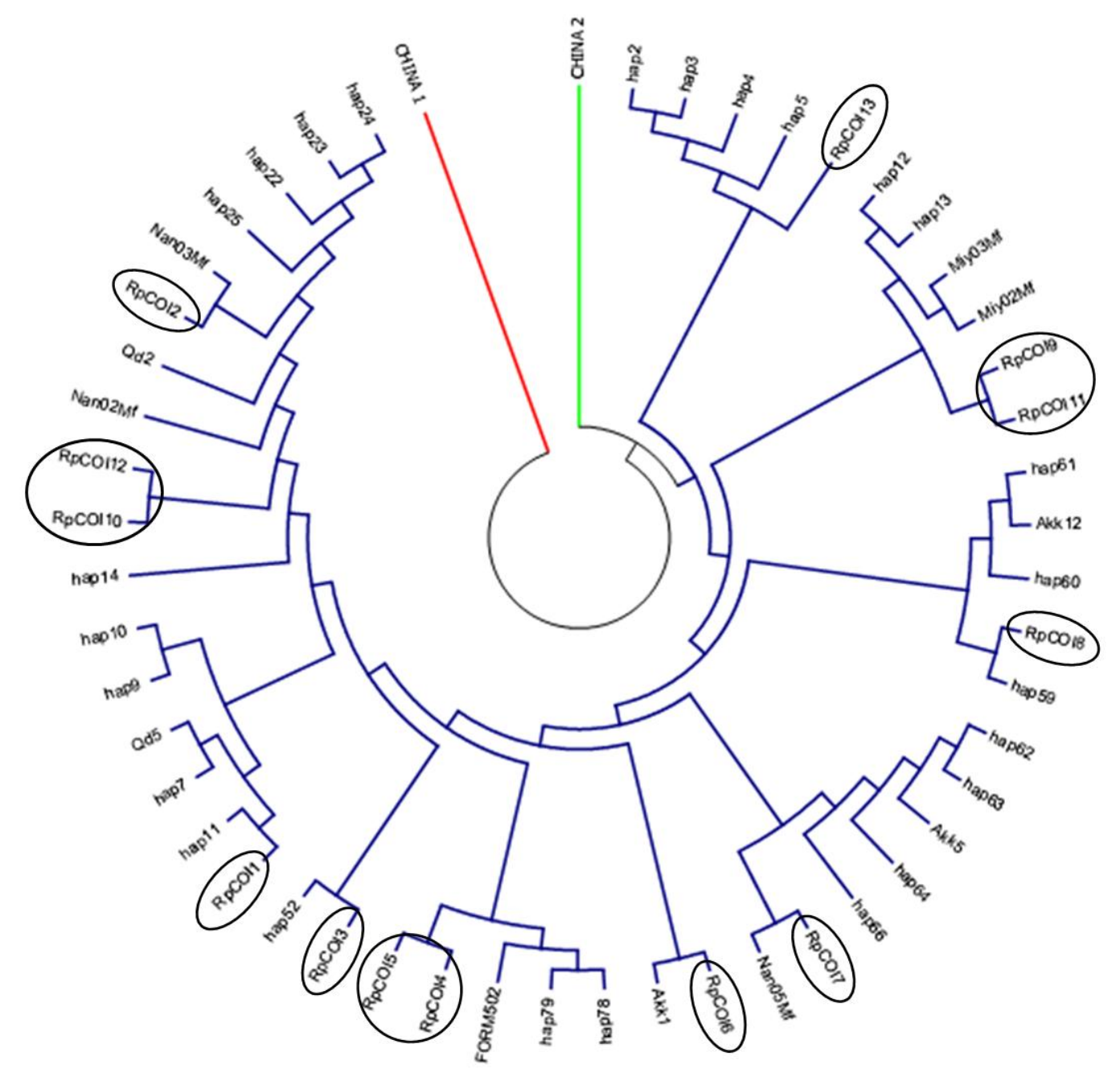

668

669 


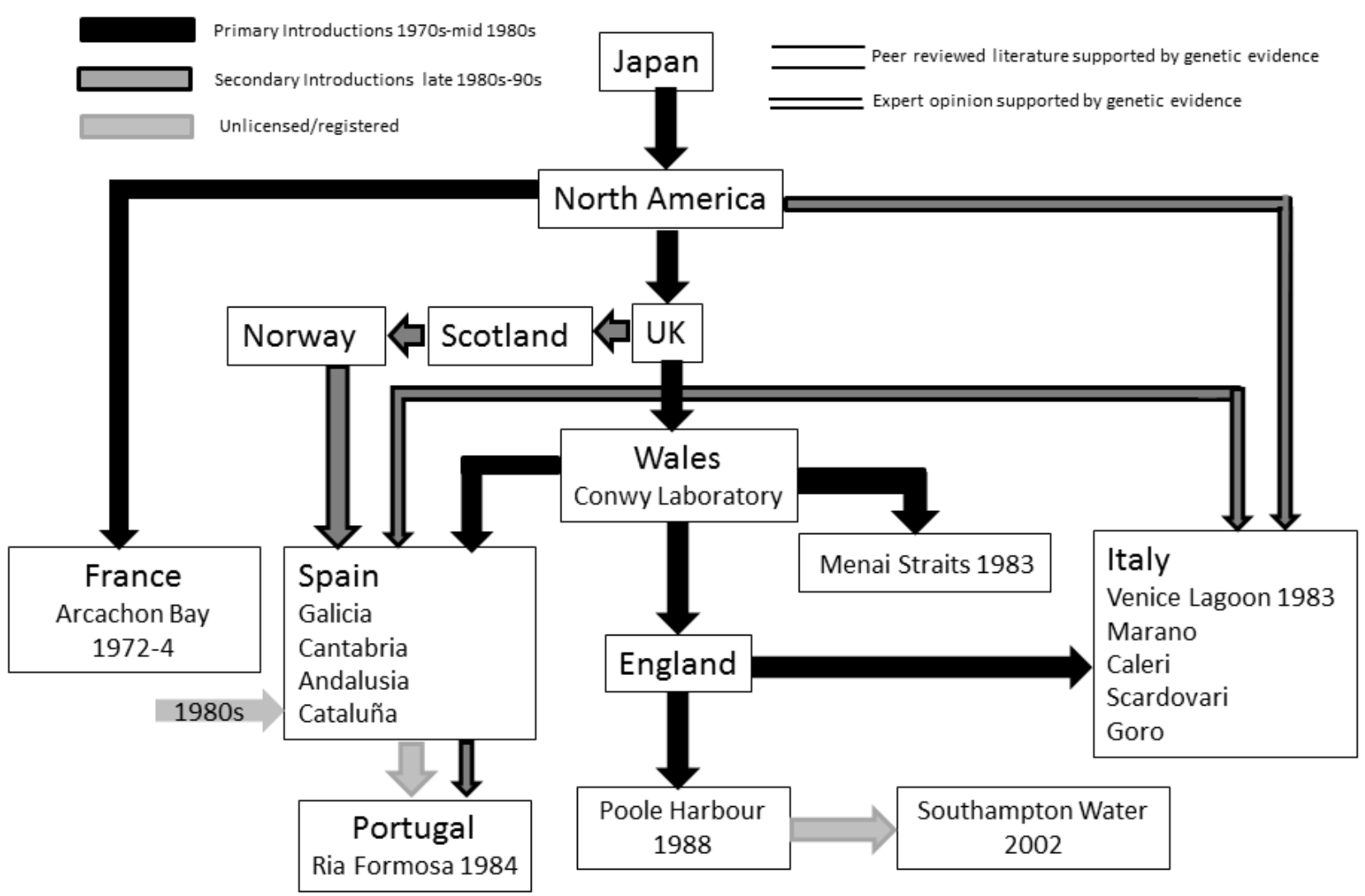

